\title{
Determinants of the Attitude of Vocational High School Students in Using Computers in Jeneponto Regency
}

\author{
Grace T. Pontoh ${ }^{1}$, Kartini Hanafi ${ }^{2}$, Endang Sriningsih $^{3}$, Eni Novitasari ${ }^{4}$ \\ \{gracetpontoh@fe.unhas.ac.id ${ }^{1}$, hanafikartini@ rocketmail.com $^{2}$, end.umsya@gmail.com ${ }^{3}$, \\ eninovitasariimron061192@gmail.com $\left.{ }^{4}\right\}$ \\ Faculty of Economics and Business, Hasanuddin University, Makassar, Indonesia. ${ }^{1,2,3}$ \\ Universitas Sulawesi Barat, Mamuju, Indonesia ${ }^{4}$
}

\begin{abstract}
The purpose of this study was to analyze the attitudes of students towards the use of computers as one of the subjects in school. This research used a survey method with data collection techniques by questionnaires with a sample of 210 students and data analyzed using AMOS statistical software. The results indicate: (1) CSE had an influence on attitudes through PEOU; (2) CA has an influence on attitudes through PEOU; (3) PE has an influence on attitudes through PEOU; and (4) PEOU has an influence on attitudes in using computers. This research contributes to the progress of science and technology with TAM and the Social Cognitive Theory which theoretically can provide evidence and support for the advancement of research in the scope of behavioral accounting. Also, teachers can form positive attitudes of students in the learning process so as to produce outstanding graduates who are able to accept technological developments.
\end{abstract}

Keywords:

computer self-efficacy, computer anxiety, perceived enjoyment, attitude

Article Received: 18 October 2020, Revised: 3 November 2020, Accepted: 24 December 2020

\section{Introduction}

The rapid development of technology and information has been characterized by the use of increasingly complex computer-based information technology in all fields. In the current field of accounting, computer technology is very important because it can speed up and simplify data processing into a fast and reliable accounting information. Computers play an important role in human life. Yudha and Ramantha (2014) states that computer systems provide several benefits over manual systems, namely speed, volume of results, error prevention, automatic posting, and automatic report preparation.

Realizing the importance of mastering this information technology, educational institutions, especially State Vocational High School I, which is a superior school in Jeneponto Regency have implemented a computerized accounting learning curriculum. Computer programs taught include MYOB Accounting, which is a computer accounting application program that is used to automate bookkeeping in a complete, fast, and accurate manner. In addition, computer technology that is taught in schools is Microsoft Office (Word, Excel, Powerpoint, and Publisher). This computer program is a challenge for accounting students because as prospective accountants they are required to have a positive attitude in using it. what determines success and failure in this case is more about how the user's attitude in using computer technology. The attitude of the user consists of components of cognition, affection and relating to behavior as indicated by an optimistic attitude that the computer is very helpful and useful in completing tasks or work. the existence of computer technology is expected to provide convenience for accounting students both in processing or processing data and posting data and finding information related to their lessons. The aspect of the attitude of the users of computer technology is influenced by the perception of ease of use. 
Some previous studies include Davis et al. (1989); Santoso (2010); Muntianah et al. (2012) who found evidence that perceived ease of use did not significantly influence the attitude of computer users. Computer self-efficacy (CSE) is a person's ability to learn computers. This refers to the accounting students' confidence that they can use computers easily so that the learning atmosphere tends not to be boring which has an impact on the quality of learning and satisfying student achievement. The ability to use each individual's computer varies depending on how strong his confidence is in the computer technology.

Computer anxiety (CA) is often associated with a positive response or an individual's negative response to the attitude of using a computer. Positive response is individuals who like computer technology if they feel that the presence of such technology will provide convenience in use and does not require heavy effort. Negative responses, namely individuals who do not like the presence of computer technology will feel anxious or excessive fear and allow them to feel intimidated in using it. This positive response and negative response can affect the individual's ease of attitudes to using computer technology. The research conducted by Venkatesh et al. (2003); Yusnaini (2010); Handayani (2010a, 2010b).

Perceived enjoyment (PE) determines a user's convenience which then leads to the attitude of the technology user in a real way. Enjoyment here is the state of a person or individual who feels comfortable when using it. The higher the level of comfort of the individual, the easier it is to use technology and ultimately the better the attitude of the individual in using computer technology. The research conducted by Santoso (2010) and Vincent et al. (2016).

Theories that will be used in this research are TAM and social cognitive theory. TAM is used in various studies of information technology, the aim is to explain the main factors of user behavior towards the acceptance of technology use. Compeau and Higgins (1995) developed a model that showed reciprocal relationships namely cognitive, environmental, and behavioral factors. This behavior is determined by individual attitudes.

The inconsistency of the results of previous studies for several computer variables selfafficacy, computer anxiety, and perceived enjoyment, perceived ease of use, and attitude in using computer technology, this research needs to be done. This research is a development by John (2015), and Vincent et al. (2016) with different objects and variables. John (2015) uses a sample of 261 permanent lecturers at the University of Waikato, New Zealand with research objects in the scope of accounting lecturers. Vincent et al. (2016) using perceived usefulness variables, perceived ease of use and perceived enjoyment. Determination of the sample is done by judgmental (purposive) technique. This study uses the object of research at the Jeneponto State Vocational School I. The chosen object of state Vocational Secondary School 1 Jeneponto is very appropriate because it is in accordance with the subject matter in this study.

\section{Literature Review}

TAM is a theory used in information technology systems. This is generally used to explain individual acceptance of the use of information technology systems. In different situations and contexts in several countries, TAM has been widely used in the field of information systems (Pontoh, 2011). This theory was developed by Davis et al. (1989) adopted from the TRA model. The TRA model was developed by Ajzen and Fishbein (1975) which came from previous research that began with attitude and behavior theory. Then Lee et al. (2003) conducted a meta-analysis to combine the results of previous TAM studies, which combined the results of 101 studies taken from 1996 to 2003 published in an open journal information systems journal. The result of this meta analysis is a complete TAM model with external variables.

Social cognitive theory was developed by Bandura in 1986. This theory is based on the premise that environmental influences affect each 
other (Bandura, 1986). Individual behavior is one of the roles of social cognitive theory. According to Bandura (1986) there are two sets of expectations as behavioral guidelines, namely expectations associated with outcome and expectations commonly called self-efficacy. Expectations associated with outcome, namely individuals who understand aspects of behavior will believe that outcome is more valuable than individuals who are unable to understand the beneficial consequences. The main characteristics of the construct of self-efficacy are the components of expertise (skill) and ability in terms of organizing and carrying out an action (Bandura, 1986).

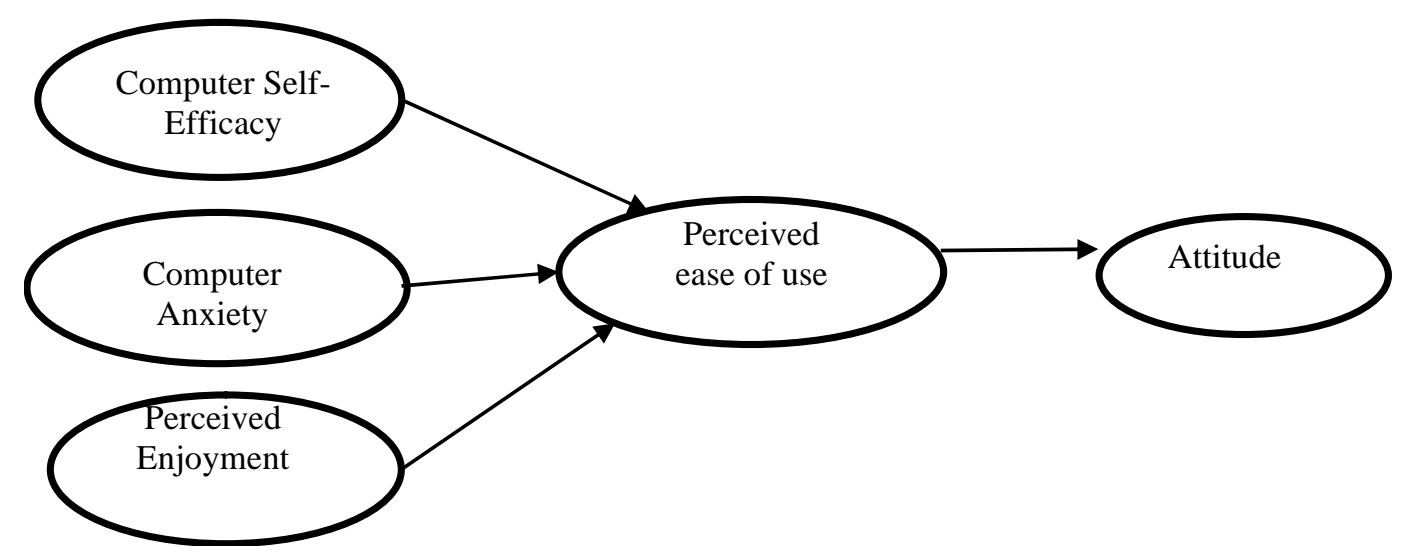

Fig. 1. Conceptual Framework

Computer self-efficacy (CSE) reflects that individuals can use the system positively and efficiently. This, it means that those who have computer trust will find it easy and have a positive attitude in using technology. Social cognitive theory (Bandura, 1986) explains that self-efficacy as an assessment of one's ability to plan and implement behaviors that lead to the achievement of a goal. Thus self-efficacy is the confidence to take action on a given task. According to Bandura (1986) there are four main sources that influence self-efficacy, namely persistent mastery and experience, perceived experience, social persuasion and psychological conditions. Kenzie et al. (1994) define computer self-efficacy as a person's confidence in his ability which can affect performance. "Self-efficacy reflects individual beliefs in their ability to perform behaviors needed to create certain outcomes that have a direct impact on the involvement of selected tasks, and the efforts shown and persistence that are associated with attitudes in using computers.
Study on the influence of computer anxiety (CA) on the attitude of computer use has been carried out by Thatcher and Perrewe (2012). Campeau and Higgins (1995) state that individuals have the capability to do tasks using computers, thus it can be formulated:

H1: CSE has a significant effect on ATT through PEOU in using computer technology.

Some studies on the influence of computer anxiety (CA) on the attitude of computer use have been carried out by Igbaria and Parasuraman (1989), Rifa and Gudono (1999), Thatcher and Perrewe (2012), Yudha and Ramantha (2014), Setyawan dan Syaefullah (2016). Researchers Igbaria and Parasuraman (1989) in their study found that a person's tendency to be difficult, worry or fear of computers computer anxiety in the present and in the future has an influence on the user's attitude towards computer technology. Therefore user negative attitudes result in low levels of computer use, high computer anxiety has a negative influence on the attitude of computer 
use. Low levels of it have confidence in selfability compared to high levels of computer anxiety. Based on previous studies it can be hypothesized that computer use with lower computer anxiety shows a higher level of computer expertise than computer users who have higher computer anxiety. Thus a hypothesis can be formulated:

H2: CA has a negative effect on ATT through PEOU in using computer technology.

The model of this study was adopted from Tangke (2004) which was developed from a study conducted by Davis et al. (1989) which uses external variables, perceived usefulness and perceived ease of use as the basis of a causal relationship of two factors that build attitudes and add perceived enjoyment variables from the research adopted from the Al-Gahtani and King (1999) study, namely perceived enjoyment variables. This variable predicts the comfort level felt by users while using computer technology. AlGahtani and King (1999) state that perceived enjoyment (PE) has a positive effect on the attitude of users of computer technology through intervening/moderating variables perceived ease of use (PEOU). The above research is supported by the results of research conducted by Santoso (2010) who found evidence that perceived enjoyment positively influences the attitude of the user. The greater the comfort level of users in using computer technology, will also affect the attitude of the user. Based on the description above, the hypothesis can be derived:

H3: PE significantly influences ATT through PEOU in using computer technology.

The concept of perceived ease of use of a technology is a level of user confidence, that someone who believes that a computer can be understood and used easily. This concept includes the clarity of the goals of technology users and the ease of use of these technologies for the intended purpose of users (Davis et al., 1989). In this case it means that if computer technology is easy to use, then users will tend to use computer technology. Perceived ease of use (PEOU) is one of the factors of the TAM model that has been tested by Davis et al. (1989) and Venkatesh et al. (2003). The results of the study can explain the reasons for individuals using technology and show that perceived ease of use has a positive and significant effect on the user's attitude. Furthermore, the research conducted by Santoso (2010), Handayani (2010) states that perceived ease of use has a positive effect on attitude. If an ease has been felt by the user in the use of a technology and the more often the technology is used so that the user's convenience will affect the attitude of the user himself. But the results of the above studies contradict the research conducted by Muntianah et al. (2012) who found evidence that perceived ease of use did not affect the user's attitude. The formation of a person's attitude to keep using a technology system depends on the convenience provided by the system so that users feel that the computer technology used can help ease their tasks. Based on the description above, the hypothesis can be derived:

H4: PEOU has a significant direct effect on ATT on the use of computer technology.

\section{Research Methods}

This research shows a picture of the factors that influence individual attitudes by using intervening variables. The research site was conducted at the Jeneponto Regency Vocational School of South Sulawesi Province. The time of the research was carried out for one year and data collection methods using a questionnaire with random sampling techniques. The unit of analysis of this research was carried out on vocational students in accounting majors using survey design by giving questionnaires to respondents, after which the questionnaires filled out by respondents were collected for the processed using AMOS version 24.

Data analysis in this research is distinguished for quantitative data. Analysis for quantitative data in the form of numbers (scores) of respondents' answers from the measurement results through a questionnaire. The measurement scale used is a Likert scale with five components. 


\section{Result}

This study uses a quantitative method and is an explanatory research that is research that explains the influence of several variables through hypothesis testing. The unit of analysis of this study was carried out on accounting students in Jeneponto using survey design by giving questionnaires to respondents, after which the questionnaires filled out by respondents were collected and processed using AMOS program assistance and explained the influence between variables and testing hypotheses that had been formulated. The population of 444 people with the sampling technique used was random sampling.

\section{Descriptive statistics}

Data regarding the characteristics of respondents revealed in this study were gender and class. The characteristics of the respondents are explained that the number of female respondents is more than the number of respondents male sex. The number of female respondents in this study was 137 people or $65.2 \%$ of the total respondents, while respondents were male as many as 73 people or $34.8 \%$ of all respondents. This identifies that accounting students are computer users dominated by female students because women tend to have higher anxiety in using computers than men. This is due to a more feminine female character than men, fear of damage, loss of data etc. can cause women to be more likely to be at the level of computer anxiety. In table 1 it is also very clear that class XI is 98 people or $46.67 \%$ of all respondents, while class XII is 112 or $53.33 \%$ of all respondents. This shows that most computer user accounting students are class XII because the students in the learning process practice more using computers than class XI, and class XII is also prepared for Job Training.

\section{Validation Test}

To test the validity used construct validity or factorial validity. Convergent validity relates to the principle that the manifest variables of a variable should be highly correlated. Validity test with AMOS can be seen from the loading factor for each construct indicator. The high value of loading factor shows that each construct indicator converges at a point. The rule of thumb used to assess convergent validity is the average variance extracted value> 0.5. Based on the results of the validity test, it can be seen that the instrument of this study has a corrected item value greater than 0.50 , so that all items in the instrument are said to be valid.

\section{Reliability Test}

Instruments are said to be reliable if used several times to measure the same object so that it will produce the same data. The technique used to test reliability is to use alpha cronbach, which is to group items into two or several parts. Reliability testing is done using the rhit standard $>0.60$, the research data is considered reliable. Based on the results of data analysis, the reliability values of all the constructs of this study have the Cronbach's Alpha value greater than 0.60 , so that all items in the instrument are said to be realiable.

\section{Testing of the Goodness of Fit Structural equation model (SEM)}

Based on the determination of the value in the model, the model testing variables are grouped into exogenous variables (CSE, CA, PE) and endogenous variables (PEOU and ATT). Exogenous variables are variables whose values are determined outside the model, while endogenous variables are variables whose values are determined through the equation or model of relationships formed. Thus it means that the complete model and the relationship of these variables indicate a model that is fit/good.

\section{Hypothesis testing}

Based on the empirical model proposed in this study hypothesis to testing will be carried out by testing the path coefficient on the structural equation model. Testing is done by looking at the $\mathrm{p}$-value if the value is smaller than 0.05 , the relationship between variables is significant. Berdasarkan Hypothesis Testing Results CSE and 
PE significantly affect the variables PEOU directly with the Sig 0,000 value $(<0.05)$. CA variables significantly affect the variable PEOU directly with the Sig. value of $0.038(<0.05)$. PEOU, and PE variables significantly influence the attitude ATT variable directly with the Sig 0.000 value $(<0.05)$. CSE significantly affects the ATT variable directly with Sig $0.013(<0.05)$.CA variables are not significant or do not directly affect the ATT variable with Sig 0.108 (> 0.05).

Statistically not all scientists agree that intervening variables cannot be measured. Baron and Kenny (1986) argue that the mediational hypothesis is generally tested in two ways, namely causal step. In the causal step strategy there are three regression equations, namely (1) independent regression of the mediator, (2) independent of dependent, and (3) independent and mediator of the dependent. Although in the causal step it is stated that there are conditions for proving a variable as intervening, but actually if the coefficients $a$ and $b$ are significant, it is sufficient to prove the existence of mediation even though $\mathrm{C}$ is not significant, namely where the independent variables influence the mediator and the mediator influences the dependent although independent is not significant affect dependency (MacKinnon, 2008). Thus, theoretically PEOU fulfills the assumption as an intervening variable. To determine the significance of indirect influences in this study used the double test.

\section{Discussion}

The analysis shows that computer selfefficacy has a significant effect on attitude through the perception of ease of use. Based on the results of the sobel test, the t-test value was 3.272 , because the $t$-test value was greater than $t$ table, which was 3.272> 1.971 with a significance level of $5 \%$, proving that perceived ease of use was able to mediate the relationship between computer self-efficacy and attitude. The results of this study support the TAM model and social cognitive theory. This study is consistent with Compeau and Higgins (1995), Rifa and Gudono
(1999), Durndell and Haag (2002) research, which have proven to be significant towards attitudes in using technology. The ease of use of computer technology can be used to increase the motivation of someone who uses an easy-to-use computer using the learning process. Based on descriptive analysis of accounting students who have confidence in using computers easily and can be understood and have a positive attitude in using computers in the learning process.

The results of the analysis of computer anxiety variables do not affect the attitude variable directly, the variable computer anxiety significantly or directly affect the perceived ease of use variable, and the perceived ease of use variable directly or affect the attitude variable directly. The results of the sobel test get a calculated t value of 2.021 because the calculated $\mathrm{t}$ value is greater than $\mathrm{t}$ table that is $2.021>1.971$ with a significance level of $5 \%$, proving that the perceived ease of use is able to mediate the relationship of the influence of computer anxiety on attitude. This explains that the lower the level of computer anxiety perceived by an individual, the higher the individual's attitude through perceived ease of use in using a computer. The results of this study support the social cognitive theory developed by Bandura (1986) and are consistent with the research findings of Heinssen et al. (1987), Igbaria and Parasuraman (1989), Harrison and Rainer (1992), Rifa and Gudono (1999), Indriantoro (2000), Sudaryono (2004), Sudaryanto and Istiati (2006), and Marietza (2013) who tested the influence computer anxiety in using computers, that computer anxiety has a significant relationship to someone's attitude in using computers. Computer anxiety can occur when students feel fear or anxiety in operating an application program that is felt to be complicated. The computer anxiety can affect students' attitudes, if computer anxiety is higher it will result in decreased attitudes of accounting students in using computers. Based on descriptive analysis shows that accounting computer students' anxiety in SMK Jeneponto has a 
significant effect on attitude with the perceived ease of use.

The results of the analysis of perceived enjoyment variables significantly influence attitudes through perceived ease of use. From the calculation of the sobel test to get the $t$ value of 5.282 because the $t$ value is greater than table that is 5.282> 1.971 with a significance level of $5 \%$, proving that the perceived ease of use is able to mediate the relationship between the effect of perceived enjoyment on attitude. This proves that the perceived enjoyment shows its influence on the attitudes of computer technology users through perceived ease of use. The results of this study support the TAM model and are consistent with the findings of Teo and Zhou (2014), Qureshi et al. (2004), Tangke (2004), Lee et al. (2003), by Qureshi et al. (2008), Santoso (2010), and Vincent et al. (2016). Vincent et al. (2016) explained that the perception of comfort has a positive impact on the attitude of the acceptance of a technological system that is mediated by the perception of ease of use. This research explains that if someone is easy to use a particular system, they will feel comfortable with the technology service so that they will be motivated to use it more often and for longer.

The results of the analysis of perceived ease of use variables significantly influence attitudes with sig values. $0,000(<0.05)$. The results of this study support the TAM model and are consistent with the findings of Szajna (1994), Tangke (2004), Al-Somali et al. (2008), Suh and Han (2002), and Chau and Lai (2003). The results showed that perceived ease of use was positively related and significantly affected user attitudes

\section{Conclusion and Suggestions}

The conclusion of this research is that CSE, $\mathrm{CA}$, and PE affect PEOU and attitudes while CA is not affected by attitudes in using computers. After mediating by perceived ease of use, computer self-efficacy, computer anxiety, and perceived enjoyment affect attitudes in using computers. The results of this study are in line with the facts in the field which reveal that a person in using computer based information technology is determined by the extent of perceived ease, confidence in computers, difficulties in using computers and the pleasure factors of their use. The easier and more pleasant use of the computer, the better the attitude of accounting students to use it.

The results of this research can provide support for accounting students in increasing the use of computer-based technology, providing support for the advancement of research in the scope of behavioral accounting, especially measuring attitudes of accounting students at the vocational level, and expected to contribute to the development of science and technology with a Technology Acceptance Model approach and Social Cognitive Theory that can theoretically provide evidence about factors that influence the attitude of computer users.

\section{References}

[1] Ajzen, I. and Fisbein, M. 1975. Belief, Attitude, Intentions and Behavior: An Introduction to Theory and Research, Addison-Wishley, Boston, MA: (Reading, Mass), USA.

[2] Al-Gahtani, S.S. and King, M. 1999. Attitudes, Satisfaction and Usage: Factors Contributing to Each in the Acceptance of Information Technology. Behavior and Information Technology, Vol.18 (4): 277297.

[3] Bandura, A. 1986. Social Foundations of Thought and Action: A Social Cognitive Theory. Englewood Cliffs, NJ: Pretice Hall.

[4] Compeau, D.R. and Higgins, C.A. 1995. Application of Social Cognitive Theory to Training for Computer Skills. Journal Information Systems Research, Vol. 6 (2): 118-143.

[5] Davis, F.D., Bagozzi, R.P. and Warshaw, P.R. 1989. User Acceptance of Computer Technology: A Comparison of Two 
Theoretical Models. Management Science, Vol. 35 (8): 982-1003.

[6] Durndell, A. and Haag, Z. 2002. Computer Self-Efficacy, Computer Anxiety, Attitudes Towards the Internet and Reported Experience with the Internet. Computers in Human Behavior, www.elsevier.com/locate/comphumbeh, Vol.18 (5): 521-35.

[7] Handayani, Rini 2010a. Analisis Faktorfaktor yang Mempengaruhi Penerimaan Penggunaan Personal Computer dengan Technology Acceptance Model. Dalam Riset Manajemen dan Akuntansi, Vol. 1 (1): 55-66.

[8] 2010b. Analisis Pengaruh Computer Anxiety dan Self-Efficacy terhadap Keahlian Penggunaan Internet pada Mahasiswa. Riset Manajemen dan Akuntansi STIE Atma Bhakti.

[9] Harrison, A.W. and Rainer.1992. The influence Of Individual Differences in End User Computing. Journal of MIS, Vol.9 (1): 93-111.

[10] Igbaria, M. and Parasuraman, S. 1989. A Path Analytic Study of Individual Characteristics, Computer Anxiety, and Attitudes toward Microcomputer. Jurnal of Management, Vol. 15 (3).

[11] John, P. Surej. 2015. The Integration of Information Technology in Higher Education: a study of faculty's attitude towards IT Adoption in the teaching process. Available online at www.sciencedirect.com.

[12] Kenzie, M.B., Delcourt, M.A.B. dan Powers, S.M. 1994. Computer Technologies: Attitudes and Self-Efficacy across Undergraduate Disciplines. Research in Higher Education, Vol. 35:745-768.

[13] Lee, Y., Kozar, Keneeth. A. and Larsen, K.R.T. 2003. The Technology Acceptance Model: Past, Present, and Future. Communication of The Association for Information System, Vol 12 :752-780.
[14] Li-hui. Z, Zhi-yong. L. and Zhi-fang, L. 2016. Application of Technology Acceptance Model in e-Learning. International Conference on Power Engineering dan Energy, Environment (PEEE 2016) ISBN: 978-1-60595-376-2.

[15] Muntianah, T.M., Astuti, E.S. and Azizah, D.F. 2012. Pengaruh Minat Perilaku terharap Actual Use Teknologi Informasi dengan Pendekatan Technology Acceptance Model (TAM). Studi Kasus pada Kegiatan Belajar Mahasiswa Fakultas Ilmu Administrasi Universitas Brawijaya Malang. E-journal Profit, Vol. 6 (1).

[16] Pontoh, T. Grace. 2011. Examining a Model of Information Technology Acceptance by Users of Enterprise Resource Planning. Manajemen \& Bisnis, Vol. 10 (2).

[17] Rifa, Dandes, and Godono. 1999. Pengaruh Faktor Demografi dan Personality terhadap Keahlian dalam EndUsing Computing. Jurnal Riset Akuntansi Indonesia, Vol. 2 (1).

[18] Santoso, Budi. 2010. Pengaruh Perceived Usefulness, Perceived Ease of Use, dan Perceived Enjoyment Terhadap Penerimaan Teknologi Informasi. Jurnal Studi Akuntansi Indonesia, Vol. 1.

[19] Setyawan, R.I. and Syaefullah. 2016. Pengaruh Computer Anxiety dan Computer Attitude Terhadap Keahlian Berkomputer Mahasiswa Akuntansi. Jurnal Ilmiah Akuntansi dan Bisnis, Vol. 11(2).

[20] Szajna, B. 1994. Software Evaluation and Choice: Predictive Validation of the Technology Acceptance Instrument. MIS Quarterly, Vol.18 (3):319-324.

[21] Tangke, Natalia. 2004. Analisa Penerimaan Penerapan Teknik Audit Berbantuan Komputer (TABK) dengan Menggunakan Technology Acceptance Model (TAM) Pada Badan Pemeriksa Keuangan (BPK) RI. Jurnal Akuntansi dan Keuangan, Vol.6 (1). 
[22] Teo, Timothy and Zhou, Mingming. 2014. Explaining the Intention to Use Technology among University Students: A Structural Equation Modeling Approach. Journal Compute High Education, Vol.26: 124-142. DOI 10.1007/s 12528-014-9080.

[23] Thatcher, J. B. and Perrewe, P.L. 2012. An empirical examination of Individual Traits as antecedents to Computer Anxiety and Computer Self Efficacy. MIS Quarterly, Vol. 26 (4), 381- 396.

[24] Venkatesh, V., Morris, M.G., Davis., G.B. and diatfa, F.D. 2003. User acceptance of information technology: Toward Anified View. Information Management, Vol. 27 (3): 425-78.

[25] Vincent, A., Nugraha, R. and Juliarsa, G. 2016. Penggunaan Sistem Informasi Akuntansi Berbasis Teknologi Informasi Dengan Model TAM. E-Jurnal Akuntansi Universitas Udayana, Vol.17 (2).

[26] Yudha.K.C. and Ramantha, I.W. 2014. Pengaruh Computer Anxiety Dan Computer Attitude Pada Keahlian Pengguna Dalam Menggunakan Komputer. Jurnal Akuntansi, Vol. 9 (3).

[27] Yusnaini. 2010. Analisis Gender dan Computer Anxiety Terhadap Keahlian Menggunakan Computer. Jurnal Ilmiah Orasi Bisnis Edisi Ke IV. 